\title{
Effect of Irrigation and Nitrogen Levels on Growth, Yield and Quality Parameters of Onion (Allium cepa L.) in Himachal Pradesh, India
}

\author{
Samir Bhatti*, J.C. Sharma and Ridham Kakar \\ Department of Soil Science and Water Management, Dr YS Parmar University of Horticulture \\ and Forestry, Nauni-Solan (HP) 173230, India \\ *Corresponding author
}

A B S T R A C T

\section{Ke y w ords \\ Onion, Irrigation and Nitrogen levels, Biological yield, Bulb yield, Number of leaves, Leaf length, Equatorial diameter and Polar diameter}

Article Info

Accepted: 04 January 2019 Available Online: 10 February 2019
Field experiments were conducted during 2015-16 and 2016-17 to study the effect of irrigation and $\mathrm{N}$ levels on growth and yield of onion (Allium cepa L.) in Himachal Pradesh. Twelve treatment combinations comprising four irrigation level i.e. $4 \mathrm{~cm}$ irrigation at IW/CPE ratio $1.2\left(\mathrm{I}_{1}\right), 1.0\left(\mathrm{I}_{2}\right), 0.8\left(\mathrm{I}_{3}\right), 0.6\left(\mathrm{I}_{4}\right)$ and three $\mathrm{N}$ levels i.e. $75\left(\mathrm{~N}_{1}\right), 100\left(\mathrm{~N}_{2}\right)$ and 125 per cent $\left(\mathrm{N}_{3}\right)$ of recommended dose of $\mathrm{N}$, were replicated thrice in a Randomized Block Design. Growth parameters viz. Bulb yield, number of leaves, leaf length, equatorial diameter, polar diameter and TSS were at par under $I_{1}$ and $I_{2}$ levels and superior over $I_{3}$ and $\mathrm{I}_{4}$. Among $\mathrm{N}$ levels, $125 \%$ of the recommended dose $\left(\mathrm{N}_{3}\right)$ was found to be optimum as it recorded significantly higher growth and yield of onion crop over $\mathrm{N}_{2}$ and $\mathrm{N}_{1}$ levels. The combinations of irrigation and $\mathrm{N}$ levels viz. $\mathrm{I}_{1} \mathrm{~N}_{3}$ and $\mathrm{I}_{2} \mathrm{~N}_{3}$ gave significantly higher bulb yield (467.0 q ha ${ }^{-1}$ and $435.5 \mathrm{q} \mathrm{ha}^{-1}$ ). The study has led to a conclusion that for maximizing growth and yield of onion in Himachal Pradesh, $4 \mathrm{~cm}$ irrigation at 1.0 IW/CPE ratio and 125 per cent of recommended dose of $N\left(I_{2} N_{3}\right)$ could be the best.

\section{Introduction}

Onion is an important crop of Himachal Pradesh, but the productivity of the crop is quite low owing to lack of assured availability of irrigation water, sub optimal and imbalanced use of fertilizer nutrients, improper management of soil and water resources and inadequate crop management practices, weed control and plant protection measures, etc. Among various factors involved, nutrient and moisture supply are important inputs for realizing higher onion yield. Irrigation scheduling is a critical management input to ensure optimum soil moisture regime for proper growth and development as well as for optimum yield and economic benefits. Well managed irrigation can lead to increased yields, greater farmer profit, and significant water savings, reduced environmental impacts and improved sustainability of irrigated agriculture (Evett et 
al., 2011; Gill et al., 2011). It has been documented that effect of irrigation and nitrogen is negligible if proper irrigation schedule is not followed. Irrigation scheduling and nitrogen levels in accordance with crop sensitivity to irrigation and nutrients during the growing cycle can hide the effects of other growth and yield affecting factors, such as rainfall amount and distribution pattern. Present study, therefore, was undertaken to determine optimum irrigation schedule and nitrogen level to achieve higher productivity of onion in Himachal Pradesh.

\section{Materials and Methods}

Field experiments were conducted during two crop years (2015-2016) at the experimental farm of Department of Soil Science and WM, Dr YS Parmar University of Horticulture and Forestry, Solan (HP). The soil (Typic Eutrochrept) was gravelly loam in texture. Salient physical and chemical properties of the experimental soil of $0-15 \mathrm{~cm}$ depth were $\mathrm{pH}$ 6.91, organic carbon (\%) 0.93, available $\mathrm{N}, \mathrm{P}$ and $\mathrm{K} 245.30,33.16$ and $260.20 \mathrm{~kg} \mathrm{ha}^{-1}$, respectively. Moisture retention at $\mathrm{FC}$ and PWP were 24.05 and 7.5 per cent in $0-15 \mathrm{~cm}$ depth, respectively. The experiment was laid out with 12 treatments replicated thrice in randomized block design. Recommended dose $(100 \%)$ of FYM, N, $\mathrm{P}_{2} \mathrm{O}_{5}$ and $\mathrm{K}_{2} \mathrm{O}$ is 25 $\mathrm{t} \mathrm{ha}{ }^{-1}, 125,75$ and $60 \mathrm{~kg} \mathrm{ha}^{-1}$, respectively, and were applied as per the treatments of the experiment in the form of Urea, single superphosphate and murate of potash. Entire dose of FYM, $\mathrm{P}$ and $\mathrm{K}$ fertilizers was applied at the time of field preparation. The $\mathrm{N}$ fertilizer was applied in two split doses, first dose at the time of transplanting and second dose one month after transplanting and third dose two months after transplanting.

Soil moisture contents in 0-7.5 and 7.5-15 cm depths were determined before and 24 hours after each irrigation to know the moisture regimes under different irrigation levels and the data has been presented for both the years of study. Plant growth parameters viz. Bulb yield, number of leaves, leaf length, equatorial diameter, polar diameter and TSS were determined at the time of harvesting of the crop. The bulb yield per hectare was calculated on the basis of per plot yield. The numbers of fully opened, grown and green leaves were recorded and average numbers of leaves per plant were worked out from five randomly selected plants. The length of leaves of five plants was recorded in centimeter $(\mathrm{cm})$ from bulb neck to tip of leaf when held vertically and the average length of leaf was worked out. The equatorial and polar diameter was measured with the help of Vernier caliper and was expressed in centimetre $(\mathrm{cm})$. Total soluble solids content of fresh bulbs were recorded with the help of hand refractometer and expressed as ${ }^{\circ}$ Brix. The data of each parameter for two crop seasons (2015-16 and 2016-17) have been presented.

\section{Results and Discussion}

\section{Soil moisture contents before and after irrigation}

Maximum soil moisture contents was noticed under $\mathrm{I}_{1}$ (4 cm irrigation at 1.2 IW/CPE ratio) irrigation level which ranged from 22.46-27.24 and 22.78-28.45 per cent with mean values of 25.94 and 26.27 per cent, which was slightly higher than the field capacity during both the years (Table 1). Minimum soil moisture contents were recorded in $\mathrm{I}_{4}$ (4 $\mathrm{cm}$ irrigation at IW/CPE ratio 0.6) irrigation level which ranged from 17.79-21.88 and 18.79-22.97 per cent with mean values of 19.72 and 20.88 per cent, which was 18.0 and 13.5 per cent lower than the field capacity during the year 2016 and 2017, respectively. In $7.5-15 \mathrm{~cm}$ depth 
after irrigation mean values varied from $17.60-22.80$ and 18.10-23.60 per cent during the year 2016 and 2017, respectively. Maximum soil moisture contents were noticed under $I_{1}$ irrigation level which ranged from 18.14-24.32 and 19.74-25.12 per cent with mean values of 22.80 and 23.60 per cent, which were near to field capacity during both the years of study. Minimum soil moisture contents were recorded in $\mathrm{I}_{4}(4 \mathrm{~cm}$ irrigation at IW/CPE ratio 0.6) irrigation level which ranged from 15.78-19.12 and 16.48-19.72 per cent with mean values of 17.60 and 18.10 per cent, which were 26.8 and 24.7 per cent lower than the field capacity during the year 2016 and 2017, respectively. Higher soil moisture contents under $\mathrm{I}_{1}$ and $\mathrm{I}_{2}$ irrigation level were due to frequent irrigations, whereas, comparatively lower moisture contents under $\mathrm{I}_{3}$ and $\mathrm{I}_{4}$ treatment were due to longer interval between successive irrigations. Higher moisture contents due to higher frequency of irrigations did not show any visual stress on various physiological processes, resulting in better uptake of nutrients and finally increased plant growth; yields attributes and yield (Kuchenbuch et al., 2006; Patel et al., 2008; Kumari, 2013).

\section{Bulb yield}

Irrigation levels exerted significant impact on bulb yield of onion (Table 2). Significantly higher (407.8 q ha ${ }^{-1}$ and $410.7 \mathrm{q} \mathrm{ha}^{-1}$ ) and lower (327.0 q ha-1 and $307.8 \mathrm{q} \mathrm{ha}^{-1}$ ) bulb yield was recorded under $\mathrm{I}_{1}$ and $\mathrm{I}_{4}$, respectively as compared to other irrigation levels, during both the years of study. Among $\mathrm{N}$ levels, maximum bulb yield (406.5 $\mathrm{q} \mathrm{ha}^{-1}$ and $408.8 \mathrm{~kg} \mathrm{ha}^{-1}$ ) and minimum (336.8 $\mathrm{q} \mathrm{ha}^{-1}$ and $329.0 \mathrm{q} \mathrm{ha}^{-1}$ ) was recorded under $\mathrm{N}_{3}$ and $\mathrm{N}_{1}$ levels, during both the years of study. In case of interaction $(\mathrm{I} \times \mathrm{N})$ significantly higher bulb yield (462.7 q ha ${ }^{-1}$ and $471.3 \mathrm{q} \mathrm{ha}^{-1}$ ) was recorded under $\mathrm{I}_{1} \mathrm{~N}_{3}$ and lower (306.0 q ha ${ }^{-1}$ and $290.7 \mathrm{q} \mathrm{ha}^{-1}$ ) under $\mathrm{I}_{4} \mathrm{~N}_{1}$ which was found to be at par with $\mathrm{I}_{4} \mathrm{~N}_{2}\left(316.7 \mathrm{q} \mathrm{ha}^{-1}\right.$ and 305.3 $\mathrm{q} \mathrm{ha}^{-1}$ ) treatment combination during both the years. Pooled analysis showed that the effect of irrigation and $\mathrm{N}$ levels was significant and the trend was almost similar during both the years of study. Maximum (409.2 q ha-1) and minimum bulb yield (317.4 q ha ${ }^{-1}$ ) was recorded under $\mathrm{I}_{1}$ and $\mathrm{I}_{4}$, respectively over other irrigation levels, whereas maximum bulb yield (407.7 $\mathrm{q} \mathrm{ha}^{-1}$ ) and minimum bulb yield $\left(334.3 \mathrm{q} \mathrm{ha}^{-1}\right)$ was recorded under $\mathrm{N}_{3}$ and $\mathrm{N}_{1}$, respectively as compared to other $\mathrm{N}$ levels. In case of interaction of irrigation and $\mathrm{N}$ levels $(\mathrm{I} \times \mathrm{N})$ maximum bulb yield $(467.0 \mathrm{q}$ $\mathrm{ha}^{-1}$ ) was recorded under 1.2 IW/CPE ratio and supplied with 125 per cent $\mathrm{N}\left(\mathrm{I}_{1} \mathrm{~N}_{3}\right)$ and minimum (303.7 $\mathrm{q} \mathrm{ha}^{-1}$ ) under 0.6 IW/CPE ratio with 75 per cent $\mathrm{N}\left(\mathrm{I}_{4} \mathrm{~N}_{1}\right)$.

\section{Number of leaves}

Data in Table 3 showed significant effect for $\mathrm{N}$ levels while, non-significant for irrigation levels and interaction effect $(\mathrm{I} \times \mathrm{N})$ and the trend was almost similar during both the years (except in second year for irrigation level). During the year 2016-17, under irrigation levels, maximum number of leaves were recorded with $\mathrm{I}_{1}$ (12.3) and minimum (11.7) under $\mathrm{I}_{4}$ level, which were statistically at par with $\mathrm{I}_{3}$ and $\mathrm{I}_{2}$ (11.8 and 11.9). Under $\mathrm{N}$ levels, significantly higher number of leaves (10.3 and 12.5) were recorded with $\mathrm{N}_{3}$ and lower (8.7 and 11.0) with $\mathrm{N}_{1}$ level, during both the years of study. Pooled analysis of the data showed that the effect of $\mathrm{N}$ was significant and higher number of leaves (11.4) was found under $\mathrm{N}_{3}$ and lower (9.9) was under $\mathrm{N}_{1}$ level. The effect of irrigation and interaction $(\mathrm{I} \times \mathrm{N})$ was non-significant.

\section{Leaf length}

Irrigation and $\mathrm{N}$ levels exerted significant effect on leaf length and the trend was almost similar during both the years (Table 4). Under 
irrigation levels maximum (39.29 and 42.62 $\mathrm{cm})$ and minimum $(29.93$ and $32.60 \mathrm{~cm})$ leaf length was recorded under $\mathrm{I}_{1}$ and $\mathrm{I}_{4}$, respectively as compared to other irrigation levels, during both the years of study. Among $\mathrm{N}$ levels, significantly higher (37.32 and $39.43 \mathrm{~cm})$ and lower $(33.67$ and $35.88 \mathrm{~cm}$ ) leaf length was recorded under $\mathrm{N}_{3}$ and $\mathrm{N}_{1}$ levels during both the years of study. In case of interaction $(\mathrm{I} \times \mathrm{N})$, maximum leaf length (41.33 and $45.27 \mathrm{~cm}$ ) was recorded under $\mathrm{I}_{1} \mathrm{~N}_{3}$ during both the years, which was statistically at par with $\mathrm{I}_{2} \mathrm{~N}_{3}(40.33 \mathrm{~cm})$ during the year 2015-16, whereas minimum $(29.00$ and $31.87 \mathrm{~cm}$ ) under $\mathrm{I}_{4} \mathrm{~N}_{1}$ during both the years, which was found to be at par with $\mathrm{I}_{4} \mathrm{~N}_{2}$ $(30.20 \mathrm{~cm})$ in $2015-16$ and $\mathrm{I}_{4} \mathrm{~N}_{2}(32.67 \mathrm{~cm})$ and $\mathrm{I}_{4} \mathrm{~N}_{3}(33.27 \mathrm{~cm})$ in 2016-17. Pooled analysis showed that the effect of irrigation and $\mathrm{N}$ levels was significant. Under irrigation levels, significantly higher $(40.96 \mathrm{~cm})$ leaf length was recorded with $\mathrm{I}_{1}$ and lower (31.27 $\mathrm{cm}$ ) with $\mathrm{I}_{4}$ level. Among $\mathrm{N}$ levels, differences were significant and maximum leaf length $(37.21 \mathrm{~cm})$ was recorded with 125 per cent $\mathrm{N}$ level $\left(\mathrm{N}_{3}\right)$ and minimum $(30.43$ $\mathrm{cm})$ with 75 per cent $\mathrm{N}$ level $\left(\mathrm{N}_{1}\right)$. The interaction effect $(\mathrm{I} \times \mathrm{N})$ was significant and maximum leaf length $(43.30 \mathrm{~cm})$ was recorded with $\mathrm{I}_{1} \mathrm{~N}_{3}$ and minimum $(30.43 \mathrm{~cm})$ under $\mathrm{I}_{4} \mathrm{~N}_{1}$ treatment combination which was at par with $\mathrm{I}_{4} \mathrm{~N}_{2}(31.43 \mathrm{~cm})$.

\section{Equatorial diameter}

Effect of irrigation and $\mathrm{N}$ levels during both the years was significant (Table 5). Under irrigation levels significantly higher (4.28 and $4.64 \mathrm{~cm})$ and lower $(3.74$ and $3.77 \mathrm{~cm}$ ) equatorial diameter was recorded under $I_{1}$ and $\mathrm{I}_{4}$, respectively over other irrigation levels, during both the years of study. Among $\mathrm{N}$ levels, maximum (4.17 and $4.53 \mathrm{~cm}$ ) and minimum $(3.80$ and $3.93 \mathrm{~cm})$ equatorial diameter was recorded under $\mathrm{N}_{3}$ and $\mathrm{N}_{1}$ levels during both the years of study. In case of interaction $(\mathrm{I} \times \mathrm{N})$ maximum (4.52 and 4.98 $\mathrm{cm})$ equatorial diameter was recorded under $\mathrm{I}_{1} \mathrm{~N}_{3}$ during both the years, which was statistically at par with $\mathrm{I}_{2} \mathrm{~N}_{3}(4.89 \mathrm{~cm})$ during the year 2016-17, whereas minimum (3.57 and $3.63 \mathrm{~cm}$ ) under $\mathrm{I}_{4} \mathrm{~N}_{1}$ during both the years, which was found to be at par with $\mathrm{I}_{4} \mathrm{~N}_{2}$ $(3.81 \mathrm{~cm}), \mathrm{I}_{4} \mathrm{~N}_{3}(3.86 \mathrm{~cm})$ and $\mathrm{I}_{3} \mathrm{~N}_{1}(3.74 \mathrm{~cm})$ in 2016-17. Pooled analysis showed that the effect of irrigation and $\mathrm{N}$ levels was significant. Under irrigation levels, significantly higher $(4.46 \mathrm{~cm})$ and lower $(3.75$ $\mathrm{cm})$ equatorial diameter was recorded with $\mathrm{I}_{1}$ and $\mathrm{I}_{4}$ levels, respectively. Among $\mathrm{N}$ levels, differences were significant and maximum equatorial diameter $(4.35 \mathrm{~cm})$ was recorded with 125 per cent $\mathrm{N}$ level $\left(\mathrm{N}_{3}\right)$ over $\mathrm{N}_{2}(4.14$ $\mathrm{cm})$ and minimum $(3.86 \mathrm{~cm})$ with 75 per cent $\mathrm{N}$ level $\left(\mathrm{N}_{1}\right)$. The interaction effect $(\mathrm{I} \times \mathrm{N})$ was significant and maximum equatorial diameter $(4.75 \mathrm{~cm})$ was recorded with $\mathrm{I}_{1} \mathrm{~N}_{3}$ and minimum $(3.86 \mathrm{~cm})$ under $\mathrm{I}_{4} \mathrm{~N}_{1}$ treatment combination.

\section{Polar diameter}

Irrigation and $\mathrm{N}$ levels exerted significant effect on polar diameter and the trend was almost similar in both the years (Table 6). Under irrigation levels, significantly higher (4.39 and $4.65 \mathrm{~cm}$ ) and lower (3.80 and 3.82 $\mathrm{cm})$ polar diameter was recorded under $\mathrm{I}_{1}$ and $\mathrm{I}_{4}$, respectively over irrigation levels, during both the years of study. Among $\mathrm{N}$ levels, significantly higher $(4.23$ and $4.56 \mathrm{~cm})$ polar diameter was recorded under $\mathrm{N}_{3}$ and minimum (3.89 and $3.95 \mathrm{~cm}$ ) was recorded under $\mathrm{N}_{1}$, during both the years of study. The effect of interaction $(\mathrm{I} \times \mathrm{N})$ was significant and the trend was almost similar for both the years. Maximum polar diameter (4.61 and $4.98 \mathrm{~cm}$ ) was recorded under $1.2 \mathrm{IW} / \mathrm{CPE}$ ratio with 125 per cent $\mathrm{N}\left(\mathrm{I}_{1} \mathrm{~N}_{3}\right)$, and minimum (3.63 and $3.63 \mathrm{~cm})$ under $0.6 \mathrm{IW} / \mathrm{CPE}$ with 75 per cent $\mathrm{N}\left(\mathrm{I}_{4} \mathrm{~N}_{1}\right)$ during both the years of study. Pooled analysis for 
this trait showed that the effect of irrigation and $\mathrm{N}$ levels was significant (Table 6). Under irrigation levels, significantly higher (4.52 $\mathrm{cm})$ polar diameter was recorded with $\mathrm{I}_{1}$ and minimum $(3.81 \mathrm{~cm})$ with $\mathrm{I}_{4}$ level. Under $\mathrm{N}$ levels, differences were significant and maximum polar diameter $(4.40 \mathrm{~cm})$ was recorded with $\mathrm{N}_{3}$ and minimum $(3.92 \mathrm{~cm}$ ) with $\mathrm{N}_{1}$ level. The interaction effect $(\mathrm{I} \times \mathrm{N})$ was significant and maximum polar diameter $(4.79 \mathrm{~cm})$ was recorded with $1.2 \mathrm{IW} / \mathrm{CPE}$ ratio and supplied with 125 per cent $\mathrm{N}\left(\mathrm{I}_{1} \mathrm{~N}_{3}\right)$ and minimum $(3.63 \mathrm{~cm})$ under $0.6 \mathrm{IW} / \mathrm{CPE}$ ratio with 75 per cent $\mathrm{N}\left(\mathrm{I}_{4} \mathrm{~N}_{1}\right)$.

The highest number of leaves, leaf length, bulb size and yield at irrigation levels $\mathrm{I}_{1}$ and $\mathrm{I}_{2}$ might be due to optimum soil moisture regimes (Table 1) throughout the growing period which might have facilitated greater nutrient uptake and proper soil physical environment to help the plants to put forth better vegetative growth, leading to higher bulb growth and yield. The present results are in accordance with the earlier findings of Lorenz and Maynard (1980), Adentuji (1990) and Lingaiah et al., (2005) and Bungard et al., (1999) in onion. They reported that the water is an essential component of photosynthesis and plays a key role in transpiration, stomatal opening and growth and expansion of leaves. In the present findings also, better performance of all the components as a result of optimum soil moisture provided by appropriate quantity of water at desired interval might have resulted in steady active plant growth and maximum possible yield. Rathore and Singh (2009) also emphasized the importance of irrigation at appropriate time as plant tissue contains more than 95 per cent of water which should be maintained for keeping the plant photosynthetically active resulting in proper growth and development and ultimately yield. Higher yield and biological yield attributes (bulb size and number of leaves) of onion in $\mathrm{N}_{3}$ might be due to complete solubility, mobilization and availability of $\mathrm{N}$ at regular interval in required quantity due to split application. Similar results were also reported by Sharma et al., (2009) in onion, Gulsum et al., (2010) in lettuce, Goudra and Rokhade (2001) in cabbage, Alam et al., (2010) in carrot, Singh et al., (2010) in potato and Tolga et al., (2010) in broccoli. Favourable effects of $\mathrm{N}$ on yield of tomato and eggplant have also been reported by Hegde and Srinivas (1989), Pal et al., (2002) and Rahman et al., (2007). The reasons suggested for such a response was that optimum $\mathrm{N}$ application increased growth parameters, which in return synthesized more plant metabolites thereby increased crop yield.

The interaction effect of irrigation and $\mathrm{N}$ levels on yield and biological yield attributes of onion was found to be significant (Table 2$6)$. These increased with higher frequency of irrigation and increasing $\mathrm{N}$ levels. The response of yield to high amounts of water and $\mathrm{N}$ application could be attributed to the favorable effect on the availability of nutrients to the plant roots, which improves the growth of the crop. Significant increase in yield due to higher $\mathrm{N}$ application might also be due to increased photosynthesis as $\mathrm{N}$ is a major constituent of chlorophyll molecule which plays an important role in photosynthesis. Increased photosynthesis results in accumulation of carbohydrates in the bulb and ultimately enhanced the plant growth and hence the yield [Neerja et al., (1999) in onion and Kemal (2014) in shallot]. These results further get support from the findings of Sanchez (2000) in lettuce, Goudra and Rokhade (2001) in cabbage, Rahman (2007) in tomato and Bozkurt et al., (2011) in cauliflower. Better expression of growth and yield under higher quantum of irrigation and $\mathrm{N}$ were also reported by Singh et al., (2010) in potato because of complimentary effect of nutrient availabilities to the plants. 


\section{Total soluble solids}

Effect of irrigation and N levels on TSS was significant. Under irrigation levels significantly higher $\left(12.27\right.$ and $\left.12.36^{\circ} \mathrm{B}\right) \mathrm{TSS}$ was observed in $\mathrm{I}_{1}$ during both the years, which was found to be at par with $\mathrm{I}_{2}(12.22$ ${ }^{\circ} \mathrm{B}$ ) in the year 2015-16, and lower (11.56 and $10.13^{\circ} \mathrm{B}$ ) TSS was observed under $\mathrm{I}_{4}$ during both the years, which was found to be at par with $\mathrm{I}_{3}\left(11.71^{\circ} \mathrm{B}\right)$ during the year $2015-16$. In case of interaction $(\mathrm{I} \times \mathrm{N})$ highest TSS $(12.80$ and $12.81{ }^{\circ} \mathrm{B}$ ) was recorded under $\mathrm{I}_{1} \mathrm{~N}_{3}$, which was at par with $\mathrm{I}_{2} \mathrm{~N}_{3}$ and $\mathrm{I}_{1} \mathrm{~N}_{2}$ (12.67 and 12.65 $\left.{ }^{\circ} \mathrm{B}\right)$ during 2015-16 and $\mathrm{I}_{2} \mathrm{~N}_{3}$ and $\mathrm{I}_{1} \mathrm{~N}_{1}(12.67$ ${ }^{\circ} \mathrm{B}$ and12.33 ${ }^{\circ} \mathrm{B}$ ) during 2016-17 (Table 7).

Table.1 Effect of irrigation levels on soil moisture contents (0-7.5 $\mathrm{cm}$ and 7.5-15 cm depths) during the year 2016 and 2017

\begin{tabular}{|c|c|c|c|c|c|c|}
\hline \multicolumn{3}{|c|}{ Treatments } & \multicolumn{4}{|c|}{ Moisture contents $(\%, w / w)$} \\
\hline & & & \multicolumn{2}{|c|}{$0-7.5 \mathrm{~cm}$ depth } & \multicolumn{2}{|c|}{$7.5-15 \mathrm{~cm}$ depth } \\
\hline & & & $\begin{array}{l}\text { Before } \\
\text { irrigation }\end{array}$ & $\begin{array}{c}\text { After } \\
\text { irrigation }\end{array}$ & $\begin{array}{l}\text { Before } \\
\text { irrigation }\end{array}$ & $\begin{array}{c}\text { After } \\
\text { Irrigation }\end{array}$ \\
\hline \multirow[t]{4}{*}{$\mathbf{I}_{\mathbf{1}}$} & \multirow[t]{2}{*}{ Range } & 2016 & $10.92-16.44$ & $22.46-27.24$ & $11.44-17.62$ & 18.14-24.32 \\
\hline & & 2017 & $11.77-16.69$ & $22.78-28.45$ & $12.52-17.92$ & $19.74-25.12$ \\
\hline & \multirow[t]{2}{*}{ Mean } & 2016 & 14.96 & 25.94 & 16.22 & 22.80 \\
\hline & & 2017 & 15.10 & 26.27 & 16.46 & 23.60 \\
\hline \multirow[t]{4}{*}{$\mathbf{I}_{2}$} & \multirow[t]{2}{*}{ Range } & 2016 & $10.22-14.08$ & $21.12-26.84$ & $11.14-15.96$ & 18.14-23.94 \\
\hline & & 2017 & $10.52-14.12$ & $21.26-27.14$ & $11.84-15.76$ & $18.66-24.24$ \\
\hline & \multirow[t]{2}{*}{ Mean } & 2016 & 13.12 & 24.14 & 14.20 & 21.86 \\
\hline & & 2017 & 13.24 & 24.58 & 14.16 & 22.26 \\
\hline \multirow[t]{4}{*}{$\mathbf{I}_{3}$} & \multirow[t]{2}{*}{ Range } & 2016 & $10.02-13.12$ & $20.88-24.24$ & $10.08-13.34$ & 17.16-21.16 \\
\hline & & 2017 & $10.16-13.18$ & $20.18-24.44$ & $10.84-13.74$ & 17.46-21.96 \\
\hline & \multirow[t]{2}{*}{ Mean } & 2016 & 11.04 & 22.48 & 12.36 & 18.86 \\
\hline & & 2017 & 11.12 & 22.84 & 12.64 & 19.18 \\
\hline \multirow[t]{4}{*}{$\mathbf{I}_{4}$} & \multirow[t]{2}{*}{ Range } & 2016 & $9.84-11.22$ & $17.79-21.88$ & $9.96-12.54$ & 15.78-19.12 \\
\hline & & 2017 & $9.64-11.04$ & $18.79-22.97$ & $10.06-12.87$ & 16.48-19.72 \\
\hline & \multirow[t]{2}{*}{ Mean } & 2016 & 10.48 & 19.72 & 11.24 & 17.60 \\
\hline & & 2017 & 10.34 & 20.88 & 11.46 & 18.10 \\
\hline
\end{tabular}


Table.2 Effect of irrigation and $\mathrm{N}$ levels on bulb yield $\left(\mathrm{q} \mathrm{ha}^{-1}\right)$

\begin{tabular}{|c|c|c|c|c|c|c|c|c|c|c|c|c|}
\hline Treatments & \multicolumn{4}{|c|}{ 2015-16 } & \multicolumn{4}{|c|}{ 2016-17 } & \multicolumn{4}{|c|}{ Pooled } \\
\hline $\mathbf{N}$ & $\mathbf{N}_{1}$ & $\mathbf{N}_{2}$ & $\mathbf{N}_{3}$ & Mean & $\mathbf{N}_{1}$ & $\mathbf{N}_{2}$ & $\mathbf{N}_{3}$ & Mean & $\mathbf{N}_{1}$ & $\mathbf{N}_{2}$ & $\mathbf{N}_{3}$ & Mean \\
\hline $\mathbf{I}_{1}$ & 370.0 & 390.7 & 462.7 & 407.8 & 354.7 & 406.0 & 471.3 & 410.7 & 362.3 & 398.3 & 467.0 & 409.2 \\
\hline $\mathbf{I}_{2}$ & 346.7 & 364.0 & 423.7 & 378.1 & 350.7 & 373.3 & 447.3 & 390.4 & 348.7 & 368.7 & 435.5 & 384.3 \\
\hline $\mathbf{I}_{3}$ & 324.7 & 340.0 & 381.3 & 348.7 & 320.0 & 357.3 & 389.3 & 355.6 & 322.3 & 348.7 & 385.3 & 352.1 \\
\hline $\mathbf{I}_{4}$ & 306.0 & 316.7 & 358.3 & 327.0 & 290.7 & 305.3 & 327.3 & 307.8 & 303.7 & 305.7 & 342.8 & 317.4 \\
\hline Mean & 336.8 & 352.8 & 406.5 & 365.4 & 329.0 & 360.5 & 408.8 & 366.1 & 334.3 & 355.3 & 407.7 & 365.8 \\
\hline $\mathrm{CD}_{(0.05)}$ & & & & & & & & & & & & \\
\hline I & & 10.2 & & & & 13.5 & & & & 7.1 & & \\
\hline $\mathbf{N}$ & & 8.9 & & & & 11.7 & & & & 6.2 & & \\
\hline $\mathbf{I} \times \mathbf{N}$ & & 17.7 & & & & 23.3 & & & & 12.4 & & \\
\hline
\end{tabular}

$\mathrm{I}_{1}:\left(1.2 \mathrm{IW} / \mathrm{CPE}\right.$ ratio), $\mathrm{I}_{2}:\left(1.0 \mathrm{IW} / \mathrm{CPE}\right.$ ratio), $\mathrm{I}_{3}:\left(0.8 \mathrm{IW} / \mathrm{CPE}\right.$ ratio), $\mathrm{I}_{4}:(0.6 \mathrm{IW} / \mathrm{CPE}$ ratio $)$

$\mathrm{N}_{1}: 75 \%$ of recommended dose of $\mathrm{N}, \mathrm{N}_{2}:$ Recommended dose of $\mathrm{N}, \mathrm{N}_{3}: 125 \%$ of recommended dose of $\mathrm{N}$

Table.3 Effect of irrigation and $\mathrm{N}$ levels on number of leaves

\begin{tabular}{|c|c|c|c|c|c|c|c|c|c|c|c|c|}
\hline Treatments & \multicolumn{4}{|c|}{ 2015-16 } & \multicolumn{4}{|c|}{ 2016-17 } & \multicolumn{4}{|c|}{ Pooled } \\
\hline${ }_{I}{ }^{N}$ & $\mathbf{N}_{1}$ & $\mathbf{N}_{2}$ & $\mathbf{N}_{3}$ & Mean & $\mathbf{N}_{1}$ & $\mathbf{N}_{2}$ & $\mathbf{N}_{3}$ & Mean & $\mathbf{N}_{1}$ & $\mathbf{N}_{2}$ & $\mathbf{N}_{3}$ & Mean \\
\hline $\mathbf{I}_{1}$ & 9.1 & 9.7 & 11.2 & 10.0 & 11.3 & 12.7 & 12.8 & 12.3 & 10.2 & 11.2 & 12.0 & 11.1 \\
\hline$I_{2}$ & 8.8 & 9.1 & 10.7 & 9.6 & 11.0 & 12.3 & 12.3 & 11.9 & 9.9 & 10.7 & 11.5 & 10.7 \\
\hline $\mathbf{I}_{3}$ & 8.5 & 9.0 & 9.9 & 9.2 & 10.8 & 12.1 & 12.3 & 11.8 & 9.7 & 10.6 & 11.1 & 10.5 \\
\hline$I_{4}$ & 8.5 & 8.5 & 9.3 & 8.8 & 11.0 & 11.5 & 12.7 & 11.7 & 9.8 & 10.0 & 11.0 & 10.3 \\
\hline Mean & 8.7 & 9.1 & 10.3 & 9.4 & 11.0 & 12.2 & 12.5 & 11.9 & 9.9 & 10.6 & 11.4 & 10.6 \\
\hline $\mathrm{CD}_{(0.05)}$ & & & & & & & & & & & & \\
\hline I & & NS & & & & 0.4 & & & & NS & & \\
\hline $\mathbf{N}$ & & 0.9 & & & & 0.4 & & & & 0.6 & & \\
\hline $\mathbf{I} \times \mathbf{N}$ & & NS & & & & NS & & & & NS & & \\
\hline
\end{tabular}

$\mathrm{I}_{1}:\left(1.2 \mathrm{IW} / \mathrm{CPE}\right.$ ratio), $\mathrm{I}_{2}:\left(1.0 \mathrm{IW} / \mathrm{CPE}\right.$ ratio), $\mathrm{I}_{3}:(0.8 \mathrm{IW} / \mathrm{CPE}$ ratio $), \mathrm{I}_{4}:(0.6 \mathrm{IW} / \mathrm{CPE}$ ratio $)$

$\mathrm{N}_{1}: 75 \%$ of recommended dose of $\mathrm{N}, \mathrm{N}_{2}$ : Recommended dose of $\mathrm{N}, \mathrm{N}_{3}: 125 \%$ of recommended dose of $\mathrm{N}$

Table.4 Effect of irrigation and $\mathrm{N}$ levels on leaf length $(\mathrm{cm})$

\begin{tabular}{|c|c|c|c|c|c|c|c|c|c|c|c|c|}
\hline Treatments & \multicolumn{4}{|c|}{ 2015-16 } & \multicolumn{4}{|c|}{ 2016-17 } & \multicolumn{4}{|c|}{ Pooled } \\
\hline $\mathrm{I}_{\mathbf{I}}^{\mathbf{N}}$ & $\mathbf{N}_{1}$ & $\mathbf{N}_{2}$ & $\mathbf{N}_{3}$ & Mean & $\mathbf{N}_{1}$ & $\mathbf{N}_{2}$ & $\mathbf{N}_{3}$ & Mean & $\mathbf{N}_{1}$ & $\mathbf{N}_{2}$ & $\mathbf{N}_{3}$ & Mean \\
\hline $\mathrm{I}_{1}$ & 37.33 & 39.20 & 41.33 & 39.29 & 39.60 & 43.00 & 45.27 & 42.62 & 38.47 & 41.10 & 43.30 & 40.96 \\
\hline $\mathbf{I}_{\mathbf{2}}$ & 35.27 & 36.33 & 40.33 & 37.31 & 37.93 & 39.93 & 41.93 & 39.93 & 36.60 & 38.13 & 41.13 & 38.62 \\
\hline $\mathbf{I}_{3}$ & 33.07 & 34.67 & 37.00 & 34.91 & 34.13 & 36.87 & 37.27 & 36.09 & 32.63 & 37.07 & 32.47 & 34.06 \\
\hline $\mathbf{I}_{4}$ & 29.00 & 30.20 & 30.60 & 29.93 & 31.87 & 32.67 & 33.27 & 32.60 & 30.43 & 31.43 & 31.93 & 31.27 \\
\hline Mean & 33.67 & 35.10 & 37.32 & 35.36 & 35.88 & 38.12 & 39.43 & 37.81 & 34.53 & 36.93 & 37.21 & 36.23 \\
\hline $\mathrm{CD}_{(0.05)}$ & & & & & & & & & & & & \\
\hline I & & 0.80 & & & & 0.98 & & & & 0.79 & & \\
\hline $\mathbf{N}$ & & 0.69 & & & & 0.85 & & & & 0.69 & & \\
\hline $\mathbf{I} \times \mathbf{N}$ & & 1.38 & & & & 1.70 & & & & 1.38 & & \\
\hline
\end{tabular}

$\mathrm{I}_{1}:\left(1.2 \mathrm{IW} / \mathrm{CPE}\right.$ ratio), $\mathrm{I}_{2}:\left(1.0 \mathrm{IW} / \mathrm{CPE}\right.$ ratio), $\mathrm{I}_{3}:(0.8 \mathrm{IW} / \mathrm{CPE}$ ratio $), \mathrm{I}_{4}:(0.6 \mathrm{IW} / \mathrm{CPE}$ ratio $)$

$\mathrm{N}_{1}: 75 \%$ of recommended dose of $\mathrm{N}, \mathrm{N}_{2}$ : Recommended dose of $\mathrm{N}, \mathrm{N}_{3}: 125 \%$ of recommended dose of $\mathrm{N}$ 
Table.5 Effect of irrigation and $\mathrm{N}$ levels on bulb equatorial diameter $(\mathrm{cm})$

\begin{tabular}{|c|c|c|c|c|c|c|c|c|c|c|c|c|}
\hline Treatments & \multicolumn{4}{|c|}{$\mathbf{2 0 1 5 - 1 6}$} & \multicolumn{4}{c|}{$\mathbf{2 0 1 6 - 1 7}$} & \multicolumn{4}{c|}{ Pooled } \\
\hline & $\mathbf{N}_{\mathbf{1}}$ & $\mathbf{N}_{\mathbf{2}}$ & $\mathbf{N}_{\mathbf{3}}$ & Mean & $\mathbf{N}_{\mathbf{1}}$ & $\mathbf{N}_{\mathbf{2}}$ & $\mathbf{N}_{\mathbf{3}}$ & Mean & $\mathbf{N}_{\mathbf{1}}$ & $\mathbf{N}_{\mathbf{2}}$ & $\mathbf{N}_{\mathbf{3}}$ & $\mathbf{M e a n}$ \\
\hline $\mathbf{I}_{\mathbf{1}}$ & 4.03 & 4.30 & 4.52 & 4.28 & 4.30 & 4.63 & 4.98 & 4.64 & 4.17 & 4.46 & 4.75 & 4.46 \\
\hline $\mathbf{I}_{\mathbf{2}}$ & 3.84 & 4.09 & 4.25 & 4.06 & 4.03 & 4.40 & 4.89 & 4.44 & 3.94 & 4.25 & 4.57 & 4.25 \\
\hline $\mathbf{I}_{\mathbf{3}}$ & 3.77 & 3.97 & 4.07 & 3.94 & 3.74 & 4.09 & 4.39 & 4.07 & 3.75 & 4.03 & 4.23 & 4.00 \\
\hline $\mathbf{I}_{\mathbf{4}}$ & 3.57 & 3.80 & 3.84 & 3.74 & 3.63 & 3.81 & 3.86 & 3.77 & 3.60 & 3.81 & 3.85 & 3.75 \\
\hline Mean & 3.80 & 4.04 & 4.17 & 4.00 & 3.93 & 4.23 & 4.53 & 4.23 & 3.86 & 4.14 & 4.35 & 4.12 \\
\hline $\mathbf{C D}_{(\mathbf{0 . 0 5})}$ & & & & & & & & & & & \\
\hline $\mathbf{I}$ & & 0.04 & & & & 0.13 & & & & 0.07 & & \\
\hline $\mathbf{N}$ & & 0.04 & & & & 0.11 & & & & 0.06 & & \\
\hline $\mathbf{I} \times \mathbf{N}$ & & 0.08 & & & & 0.23 & & & & 0.13 & & \\
\hline
\end{tabular}

$\mathrm{I}_{1}:\left(1.2 \mathrm{IW} / \mathrm{CPE}\right.$ ratio), $\mathrm{I}_{2}:\left(1.0 \mathrm{IW} / \mathrm{CPE}\right.$ ratio), $\mathrm{I}_{3}:\left(0.8 \mathrm{IW} / \mathrm{CPE}\right.$ ratio), $\mathrm{I}_{4}:(0.6 \mathrm{IW} / \mathrm{CPE}$ ratio $)$

$\mathrm{N}_{1}: 75 \%$ of recommended dose of $\mathrm{N}, \mathrm{N}_{2}$ : Recommended dose of $\mathrm{N}, \mathrm{N}_{3}: 125 \%$ of recommended dose of $\mathrm{N}$

Table.6 Effect of irrigation and N levels on bulb polar diameter $(\mathrm{cm})$

\begin{tabular}{|c|c|c|c|c|c|c|c|c|c|c|c|c|}
\hline Treatments & \multicolumn{4}{|c|}{ 2015-16 } & \multicolumn{4}{|c|}{ 2016-17 } & \multicolumn{4}{|c|}{ Pooled } \\
\hline $\mathbf{I}^{\mathbf{N}}$ & $\mathbf{N}_{1}$ & $\mathbf{N}_{2}$ & $\mathbf{N}_{3}$ & Mean & $\mathbf{N}_{1}$ & $\mathbf{N}_{2}$ & $\mathbf{N}_{3}$ & Mean & $\mathbf{N}_{1}$ & $\mathbf{N}_{2}$ & $\mathbf{N}_{3}$ & Mean \\
\hline $\mathbf{I}_{1}$ & 4.17 & 4.39 & 4.61 & 4.39 & 4.33 & 4.63 & 4.98 & 4.65 & 4.25 & 4.51 & 4.79 & 4.52 \\
\hline $\mathbf{I}_{2}$ & 3.92 & 4.19 & 4.30 & 4.14 & 4.03 & 4.45 & 4.89 & 4.46 & 3.98 & 4.32 & 4.60 & 4.30 \\
\hline $\mathbf{I}_{3}$ & 3.82 & 4.05 & 4.13 & 4.00 & 3.79 & 4.09 & 4.39 & 4.09 & 3.81 & 4.07 & 4.26 & 4.05 \\
\hline $\mathbf{I}_{4}$ & 3.63 & 3.87 & 3.89 & 3.80 & 3.63 & 3.84 & 3.99 & 3.82 & 3.63 & 3.86 & 3.94 & 3.81 \\
\hline Mean & 3.89 & 4.13 & 4.23 & 4.08 & 3.95 & 4.25 & 4.56 & 4.25 & 3.92 & 4.19 & 4.40 & 4.17 \\
\hline$C D_{(0.05)}$ & & & & & & & & & & & & \\
\hline I & & 0.05 & & & & 0.01 & & & & 0.05 & & \\
\hline $\mathbf{N}$ & & 0.04 & & & & 0.08 & & & & 0.05 & & \\
\hline $\mathbf{I} \times \mathbf{N}$ & & 0.08 & & & & 0.17 & & & & 0.09 & & \\
\hline
\end{tabular}

$\mathrm{I}_{1}:\left(1.2 \mathrm{IW} / \mathrm{CPE}\right.$ ratio), $\mathrm{I}_{2}:\left(1.0 \mathrm{IW} / \mathrm{CPE}\right.$ ratio), $\mathrm{I}_{3}:(0.8 \mathrm{IW} / \mathrm{CPE}$ ratio $), \mathrm{I}_{4}:(0.6 \mathrm{IW} / \mathrm{CPE}$ ratio $)$

$\mathrm{N}_{1}: 75 \%$ of recommended dose of $\mathrm{N}, \mathrm{N}_{2}$ : Recommended dose of $\mathrm{N}, \mathrm{N}_{3}: 125 \%$ of recommended dose of $\mathrm{N}$

Table.7 Effect of irrigation and N levels on TSS $\left({ }^{\circ}\right.$ Brix)

\begin{tabular}{|c|c|c|c|c|c|c|c|c|c|c|c|c|}
\hline Treatments & \multicolumn{4}{|c|}{ 2015-16 } & \multicolumn{4}{|c|}{ 2016-17 } & \multicolumn{4}{|c|}{ Pooled } \\
\hline $\mathrm{I}^{\mathrm{N}}$ & $\mathbf{N}_{1}$ & $\mathbf{N}_{2}$ & $\mathbf{N}_{3}$ & Mean & $\mathbf{N}_{1}$ & $\mathbf{N}_{2}$ & $\mathbf{N}_{3}$ & Mean & $\mathbf{N}_{1}$ & $\mathbf{N}_{2}$ & $\mathbf{N}_{3}$ & Mean \\
\hline $\mathbf{I}_{1}$ & 11.33 & 12.67 & 12.80 & 12.27 & 12.33 & 11.93 & 12.81 & 12.36 & 11.83 & 12.30 & 12.80 & 12.31 \\
\hline $\mathbf{I}_{2}$ & 11.67 & 12.33 & 12.67 & 12.22 & 10.80 & 11.80 & 12.65 & 11.76 & 10.90 & 12.07 & 12.67 & 11.88 \\
\hline $\mathbf{I}_{3}$ & 10.67 & 12.00 & 12.47 & 11.71 & 10.53 & 11.27 & 11.80 & 11.20 & 10.60 & 11.63 & 12.13 & 11.46 \\
\hline $\mathbf{I}_{4}$ & 10.47 & 11.53 & 12.67 & 11.56 & 9.60 & 9.93 & 10.87 & 10.13 & 10.03 & 10.73 & 11.77 & 10.84 \\
\hline Mean & 11.03 & 12.13 & 12.65 & 11.94 & 10.82 & 11.23 & 12.03 & 11.36 & 10.84 & 11.68 & 12.34 & 11.62 \\
\hline $\mathrm{CD}_{(0.05)}$ & & & & & & & & & & & & \\
\hline I & & 0.23 & & & & 0.36 & & & & 0.20 & & \\
\hline $\mathbf{N}$ & & 0.20 & & & & 0.31 & & & & 0.17 & & \\
\hline $\mathbf{I} \times \mathbf{N}$ & & 0.39 & & & & 0.63 & & & & 0.34 & & \\
\hline
\end{tabular}

$\mathrm{I}_{1}:\left(1.2 \mathrm{IW} / \mathrm{CPE}\right.$ ratio), $\mathrm{I}_{2}:\left(1.0 \mathrm{IW} / \mathrm{CPE}\right.$ ratio), $\mathrm{I}_{3}:(0.8 \mathrm{IW} / \mathrm{CPE}$ ratio $), \mathrm{I}_{4}:(0.6 \mathrm{IW} / \mathrm{CPE}$ ratio $)$

$\mathrm{N}_{1}: 75 \%$ of recommended dose of $\mathrm{N}, \mathrm{N}_{2}$ : Recommended dose of $\mathrm{N}, \mathrm{N}_{3}: 125 \%$ of recommended dose of $\mathrm{N}$ 
Lowest (10.47 and $\left.9.60^{\circ} \mathrm{B}\right)$ TSS was recorded under $\mathrm{I}_{4} \mathrm{~N}_{1}$ during both the years, which was at par with $\mathrm{I}_{3} \mathrm{~N}_{1}\left(10.67{ }^{\circ} \mathrm{B}\right)$ during 2015-16 and $\mathrm{I}_{4} \mathrm{~N}_{2}\left(9.93{ }^{\circ} \mathrm{B}\right)$ during 2016-17. Pooled analysis showed that the effect of irrigation and $\mathrm{N}$ levels was significant. Under irrigation levels, significantly higher TSS $\left(12.31^{\circ} \mathrm{B}\right)$ was recorded with $\mathrm{I}_{1}$ and lower $\left(10.84{ }^{\circ} \mathrm{B}\right)$ with $\mathrm{I}_{4}$ level. Under $\mathrm{N}$ levels, differences were significant and highest TSS $\left(12.34{ }^{\circ} \mathrm{B}\right)$ was recorded with 125 per cent $\mathrm{N}$ level $\left(\mathrm{N}_{3}\right)$ over $\mathrm{N}_{2}\left(11.68^{\circ} \mathrm{B}\right)$ and minimum $\left(10.84^{\circ} \mathrm{B}\right)$ with 75 per cent $\mathrm{N}$ level $\left(\mathrm{N}_{1}\right)$. The interaction effect $(\mathrm{I} \times \mathrm{N})$ was also statistically significant and higher TSS $\left(12.80^{\circ} \mathrm{B}\right)$ was recorded with irrigation at 1.2 IW/CPE ratio and supplied with 125 per cent $\mathrm{N}\left(\mathrm{I}_{1} \mathrm{~N}_{3}\right)$ which was at par with $\mathrm{I}_{2} \mathrm{~N}_{3}\left(12.67^{\circ} \mathrm{B}\right)$ and minimum TSS $\left(10.03{ }^{\circ} \mathrm{B}\right)$ under $0.6 \mathrm{IW} / \mathrm{CPE}$ ratio with 75 per cent $\mathrm{N}\left(\mathrm{I}_{4} \mathrm{~N}_{1}\right)$.

Change in TSS with irrigation may probably be due to fulfillment of crop water demand and better utilization of nutrient under optimum moisture availability. The results are in consonance with the findings of Chopade et al., (1998) and Fatideh and Asil (2012) in onion.

The study has led to a conclusion that for maximizing growth and yield of onion in Himachal Pradesh, $4 \mathrm{~cm}$ irrigation at 1.0 IW/CPE ratio and 125 per cent of recommended dose $\mathrm{N}$ (I2N3) could be the best.

\section{References}

Adetunji, I.A. 1990. Effect of mulches and irrigation on growth and yield of lettuce in semi arid region. Biotronics 19: 9398

Alam, M.S., Mallik, S.A. and Costa, D.J. 2010. Effect of irrigation on growth and yield of (Daucus carota ssp. sativus) carrot in hill valley. Bangladesh
Journal of Agricultural Research 35: 323- 329.

Bozkurt, S. and Mansuroglu, G.S. 2011. Lettuce yield responses to different drip irrigation levels under open field condition. Journal of Cell and Plant Science 2: 12-18.

Bungard, R.A, Wingler, A., Morton, J.D. and Andrews, M. 1999. Ammonium can stimulate nitrate and nitrite reductase in the absence of nitrate in Climatis vitalba. Plant Cell Environment 22: 859-866.

Chopade, S.O., Bansode, P.N and Hiwase, S.S. 1998. Studies on fertilizer and water management to onion. PKV Research Journal 22: 44-47.

Evett, S.R, Schwartz, R., Mazahrih, N.T., Jitan, M.A. and Shaqir, I.M. 2011. Soil water sensors for irrigation scheduling: Can they deliver a management allowed depletion, (ed.) U. Yermiyahu, A BenGal, A Dag 888: 231-238

Fatideh, M.M. and Asil, M.H. 2012. Onion yield, quality and storability as affected with different soil moisture and nitrogen regimes. South Western Journal of Horticulture, Biology and Environment 3: 145-165.

Gill, G., Humphreys, E., Kukal, S., and Walia, U. 2011. Effect of water management on dry seeded and puddled transplanted rice. Part 1: Crop performance. Field Crops Research 120(1): 112-122.

Goudra, K.H.B. and Rokhade, A.K. 2001. Effect of irrigation schedules and methods on growth and yield of cabbage. Journal of Agricultural Science 14: 721-723.

Gulsum, S.M., Sefer, B., Melisa, K. and Selda, T. 2010. The effects of nitrogen forms and rates under different irrigation levels on yield and plant growth of lettuce. Journal of Cell and Plant Science 1: 33-40.

Hegde, D.M. and Srinivas, K.1989. Studies on irrigation and nitrogen requirement of tomato. Indian Journal of Agronomy 34: 157-162.

Kemal, Y.O. 2014. Effects of irrigation and 
nitrogen levels on bulb yield, nitrogen uptake and water use efficiency of shallot (Allium cepa var. ascalonicum Baker). African Journal of Agricultural Research 8: 4637-4643.

Kuchenbuch, R.O., Ingram, K.T. and Buczko, U. 2006. Effects of decreasing soil water content on seminal and lateral roots of young maize plants. Journal of Plant Nutrition and Soil Science 169: 814-848.

Kumari, M. 2013. Scheduling of irrigation in cauliflower (Brassica oleracea var. botrytis L.) under mid hill conditions of Himachal Pradesh. M.Sc. Thesis. Department of Soil Science and Water Management, Dr Yaswant singh Parmar University of Horticulture and Forestry, Solan.81p.

Lingaiah, D., Katti, G.S. and Shaik, M. 2005. Influence of drip irrigation on crop growth, yield and water use efficiency in cabbage (Brassica oleracea). International Journal of Agricultural Sciences 1: 110-111.

Lorenz, O.A. and Maynard, D.N. 1980. Knoff's Handbook for Vegetable Growers. 2nd edn.

Neeraja, G., Reddy, K.M., Reddy, I.P., Reddy, Y.N. 1999. Effect of irrigation and nitrogen on growth, yield and yield attributes of rabi onion (Allium cepa L.) in Andhra Pradesh. Vegetable Sciences 26: 64-68.

Patel, G.N., Patel, P.T. and Patel, P.H. 2008. Yield, water use efficiency and moisture extraction pattern of summer groundnut as influenced by irrigation schedules, sulphur levels and sources. Journal of Agriculture Research, 6: 1-4.
Rahman, M.J., Mondol, M.A.I., Rahman, M.N., Begum, R.A. and Alam, M.K. 2007. Effect of irrigation and nitrogen on tomato yield in the grey terrace soil of Bangladesh. Journal of Soil Nature 1: $1-4$.

Rathore, A.C. and Singh, J.N. 2009. Optimization of nitrogen application and irrigation for improved growth and spike production of tuberose (Polianthus tuberose L.). Indian Journal of Soil Conservation 37: 45-49.

Sanchez, C.H.A. 2000. Response of lettuce to water and nitrogen on sand and the potential for leaching of nitrate-N. Horticulture Science 35: 73-75.

Sharma, R.P., Datt, N. and Chander, G. 2009. Effect of vermicompost, farmyard manure and chemical fertilizers on yield, nutrient uptake and soil fertility in okra (Abelmoschus esculentus)-onion (Allium сера $\mathrm{L}$.) sequence in wet temperate zone of Himachal Pradesh. Journal of the Indian Society of Soil Science 57: 357361.

Singh, N., Sood, M.C. and Singh, S.P. 2010. Optimizing irrigation water and nutrient requirement of potato (Solanum tuberosum L.) under drip fertigation. Progressive Agriculture 10: 192- 195.

Tolga, E., Levent, A., Yesim, E., Serdar, P., Murat, D., Hakan, O. and Huseyin, T.G. 2010. Yield and quality response of drip irrigated broccoli (Brassica oleracea L. var. italica) under different irrigation regimes, nitrogen applications and cultivation periods. Agricultural Water Management 97: 681-688.

\section{How to cite this article:}

Samir Bhatti, J.C. Sharma and Ridham Kakar. 2019. Effect of Irrigation and Nitrogen Levels on Growth, Yield and Quality Parameters of Onion (Allium cepa L.) in Himachal Pradesh, India. Int.J.Curr.Microbiol.App.Sci. 8(02): 409-418. doi: https://doi.org/10.20546/ijcmas.2019.802.046 